\title{
Water Characteristics and Microbial Flora in a Lagoon System for Wastewater from a Paddock of Dairy Cattle
}

\author{
Yutaka NAKAI, Takashi ABE, Chikara KOHDA and Tasuke ANDO \\ Faculty of Agriculture, Tohoku University, Aoba-ku, Sendai-shi 981-8555, Japan
}

(Received July 8, 1998 ; Accepted November 17, 1998)

\begin{abstract}
Water qualities and microorganisms in a lagoon which was used for the treatment of the wastewater from a paddock in a dairy farm were investigated seasonally. Biochemical oxygen demand, suspended solid and total nitrogen were decreased by the lagoon treatment to meet the general requirements for the wastewater discharge in Japan year-around. Ammonium nitrogen was also decreased by the treatment ; howcver, concentrations of nitrite and nitrate were very low in any basin of the lagoon. The levels of microbes aerobically and anaerobically cultured tended to be decreased by the treatment ; however, the levels of these microbes in each basin of the lagoon were relatively stable year-around. Spore-forming bacteria such as bacilli and clostridia were relatively large in number in the lagoon. The levels of enterobacteriaceae and streptococci tended to be decreased by the treatment, which suggested that these fecal bacteria were eliminated in the lagoon. Fungi and actinomycetes were small in number. Ammonia- or nitrite-oxidizing microbes were almost less than the detectable level, which agree with the low concentrations of nitrite and nitrate in the lagoon. This suggested that a limited amount of ammonia was nitrified, and ammonia in the wastewater was removed not by nitrification but by assimilation of microbes. Microbial assimilation of ammonia may be one of the important processes in the wastewater treatment by the lagoon.
\end{abstract}

Animal Science Journal 70 (1) : 38-42. 1999

Key words : Cattle, Microbial flora, Lagoon, Nitrification, Wastewater

Lagoon systems are convenient and inexpensive systems for treatment of the wastewater. In operations having a large area, the system is suitable for the animal production. Treated water can be re-used in the farm for flushing floors and so on, and accumulated sludge can be used as fertilizer. This system is one of recyclable and sustainable systems.

Although the systems are used worldwide, a limited number of researches were performed about the lagoon system ${ }^{7,10,11)}$, compared with researches about treatment systems of activated sludge. Moreover, few researches were done in microorganisms in lagoons. Microbiological investigation of lagoons will provide a basic knowledge for improving lagoon systems. Here we report characteristics of water and microbes in a lagoon system which is used for wastewater treatment of a paddock of dairy cattle.

\section{Materials and Methods}

\section{Sampling}

We focused on a lagoon in Iwate Prefecture (Fig. 1). The lagoon consisted of 6 basins (No. 1-6) which were connected straightly. The wastewater from the paddock of dairy cattle flowed into No. 1 basin. The treated water in No. 1 basin overflowed into No. 2 basin, and the water overflowed down successively. Although No. 1 basin was weakly aerated by an air pump, the other basins were not aerated. The horizontal size of each basin was $10 \mathrm{~m}$ by $10 \mathrm{~m}$. No. 1 basin was constructed of concrete

Corresponding : Yutaka NAKAI (fax : +81 (0) 22-717-8710, e-mail : nakai@bios.tohoku.ac.jp)

Anim. Sci. J. 70 (1) : 38-42, 1999 


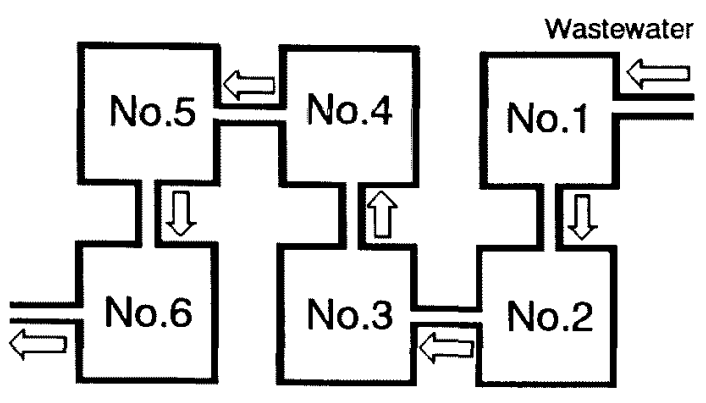

Fig. 1. The lagoon system.

and about $2 \mathrm{~m}$ in depth, and No. 2-6 basins were earthen impounded and about $2 \mathrm{~m}$ in depth. Samples of water were taken from the surface of No. 1, No. 2 and No. 6 basin with $2 l$ scoop in the morning on June 1, August 31, October 31 and December 19 in 1995 and on June 11, August 27, October 31 and December 13 in 1996, respectively. The dates for the sampling were decided by avoiding rainy days and the days just after heavy rains. Since each seasonal data in 1995 were similar to the corresponding data in 1996, data in 1996 were mainly used in the text and tables. The influx volume and retention time of the wastewater in the basins were not determined, because the influx was not constant.

\section{Water characteristics}

Water characteristics were measured by the Japanese standard methods ${ }^{2)}$. Briefly, biochemical oxygen demand (BOD) and chemical oxygen demand (COD) were determined by measuring decrease of dissolved oxygen after 5-day incubation and potassium permanganate oxidation method, respectively. Suspended solid (SS) was determined by the membrane method. Ammonium-nitrogen $\left(\mathrm{NH}_{4}-\mathrm{N}\right)$, nitrite- $\mathrm{N}\left(\mathrm{NO}_{2}-\mathrm{N}\right)$ and nitrate- $\mathrm{N}\left(\mathrm{NO}_{3}-\mathrm{N}\right)$ were measured by the salicylic-acid method, the diazotization method and the cadmium reduction method, respectively. Total-nitrogen (T-N) and total phosphorus (T-P) were determined by potassium-disulfateoxidation method and ascorbic-acid method, respectively. Phosphate-P $\left(\mathbf{P O}_{4}-\mathbf{P}\right)$ were measured by the molybdic blue extraction method.

\section{Identification and counting of microorganisms}

Microorganisms were isolated and classified by the routine methods using non-selective and selective media as mentioned previously ${ }^{8)}$. Briefly, trypticase soy blood (TS) agar (Nissui Seiyaku, Tokyo) was used as non-selective medium for aerobic microbes, deoxycholate hydrogen sulfide lactose (DHL) agar (Nissui) for enterobacteriaceae, triphenyltetrazolium chloride-acridine orange-thallous sulfate aesculin crystal violet (TATAC) agar (Nissui) for streptococci, nalidixic-acid centrimide (NAC) agar (Eiken, Tokyo) for pseudomonads, and potato dextrose (PD) agar (Difco, Detroit, MI, USA) with tartaric acid for fungi. For anaerobic growth of bacteria, blood liver (BL) agar (Nissui) was used as a non-selective medium. After heat treatment of samples at $70^{\circ} \mathrm{C}$ for $10 \mathrm{~min}$, numbers of bacilli and clostridia were determined by TS agar or BL agar, respectively. Actinomycetes were counted by the method of Hayakawa et al. ${ }^{6}$. Numbers of ammonia-oxidizing bacteria and nitrite-oxidizing bacteria were determined by the method of Alexander et al. ${ }^{3)}$. The number of bacteria on TS agar plate and that on BL agar plate were expressed in this study as the number of aerobically cultured microbes and anaerobically cultured microbes, respectively.

\section{Results and Discussion}

\section{Water characteristics}

Although water temperature seasonally changed, $\mathrm{pH}$ was almost stable (Table 1). BOD was decreased by the lagoon treatment (Table 2). BOD of No. 6 basin in all seasons met the general requirements for the wastewater discharge in Japan $(160 \mathrm{mg}$ / l). COD was also decreased by the treatment; however, that in autumn only met the requirements (160 $\mathrm{mg} / \mathrm{l})$. The treated water showed deep brown color, which may cause higher COD. We often experienced that BOD was significantly decreased but COD remained high in the process of treatment of the wastewater in many animal farms. Since there is possibility that the lagoon water with higher level of COD overflow into the streams, a holding pond was recently constructed to store lagoon efluent in the farm. SS of No. 6 basin met the requirements yearround $(200 \mathrm{mg} / \mathrm{l})$. Total nitrogen (Table 3 ) was decreased by the treatment to the level less than the requirements $(120 \mathrm{mg} / l)$. The values of $\mathrm{NH}_{4}-\mathrm{N}$ were 
also decreased by the treatment; however, very low concentrations of $\mathrm{NO}_{2}-\mathrm{N}$ and $\mathrm{NO}_{3}-\mathrm{N}$ were detected in most of basins. This suggested that nitrification proceeded at a low rate in the lagoon. Total phosphorus (Table 4) was decreased by the treatment, and the levels except those in summer met the requirements $(16 \mathrm{mg} / \mathrm{l})$. Phosphoric phosphorus was also decreased by the treatment in any seasons.

These results showed that the water quality of the supernatant of the last basin almost met the general

Table 1. Water characteristics (temperature, ${ }^{\circ} \mathrm{C}$; $\mathrm{pH}$ ) in the lagoon

\begin{tabular}{|c|c|c|c|c|c|c|c|c|}
\hline \multirow{2}{*}{ Basin } & \multicolumn{4}{|c|}{ Water temperature } & \multicolumn{4}{|c|}{$\mathrm{pH}$} \\
\hline & $\mathrm{Sp}^{1)}$ & Su & $\mathrm{Au}$ & $\mathrm{Wi}_{\mathrm{i}}$ & $\mathrm{Sp}$ & Su & $\mathrm{Au}$ & Wi \\
\hline No. 1 & 17.9 & 22.6 & 15.5 & 5.9 & 7.0 & 7.1 & 7.2 & 7.0 \\
\hline No. 2 & 18.6 & 22.2 & 14. 7 & 6.3 & 7. 2 & 7.1 & 7.4 & 6.9 \\
\hline No. 6 & 17.0 & 20.7 & 11.8 & 3.0 & 7.6 & 7.3 & 7.6 & 7.0 \\
\hline
\end{tabular}

${ }^{1)}$ Samples were obtained on June 11 (Sp), August 27 $(\mathrm{Su})$, October $31(\mathrm{Au})$, and December $13(\mathrm{Wi})$ in 1996. requirement for wastewater discharge in Japan. When an additional treatment system is combined, the lagoon system can be a suitable method for the treatment of wastewater in farms.

\section{Microorganisms}

The levels of aerobically and anaerobically cultured microbes tended to be decreased by the treatment; however, the levels in each basin was relatively stable year-around (Table 5). This indicated that the levels of microbes were less affected by the seasonal conditions. Small number of fungi was detected. Actinomycctes was also small in number (Table 6). Among the bacterial groups investigated, the levels of pseudomonads were the smallest and those of bacilli were relatively large. The levels of enterobacteriaceae and streptococci tended to be decreased by the treatment. This suggested that these fecal bacteria were eliminated from the microbial flora in the lagoon (Table 7). Almost all of the levels of clostridia were as high as those of bacilli. This indicated that such spore-forming bacteria existed in larger numbers in the lagoon, and that spore-forming bacteria overcame intestinal bacteria. The

Table 2. Water characteristics (biochemical oxygen demand, BOD ; chemical oxygen demand, COD and suspended solid, SS in $\mathrm{mg} / l$ ) in the lagoon

\begin{tabular}{|c|c|c|c|c|c|c|c|c|c|c|c|c|}
\hline \multirow{2}{*}{ Basin } & \multicolumn{4}{|c|}{ BOD } & \multicolumn{4}{|c|}{$\mathrm{COD}$} & \multicolumn{4}{|c|}{ SS } \\
\hline & $\mathrm{Sp}^{1)}$ & $\mathrm{Su}$ & $\mathrm{Au}$ & $\mathrm{Wi}$ & $\mathrm{Sp}$ & $\mathrm{Su}$ & $\mathrm{Au}$ & Wi & $\mathrm{Sp}$ & $\mathrm{Su}$ & $\mathrm{Au}$ & $\mathrm{Wi}^{*}$ \\
\hline No. 1 & 576 & 110 & 42 & 388 & 850 & 230 & 1.43 & 402 & 36 & 80 & 66 & 405 \\
\hline No. 2 & 70 & 110 & 29 & 302 & 388 & 280 & 113 & 376 & 8 & 113 & 43 & 204 \\
\hline No. 6 & 58 & 120 & 7 & 93 & 288 & 210 & 60 & 169 & 33 & 72 & 20 & 53 \\
\hline
\end{tabular}

1) The same samples in Table 1 except $\left(^{*}\right)$, of which data were on December 19 in 1995.

Table 3. Water characteristics (total nitrogen, $\mathrm{T}-\mathrm{N}$; ammonium-nitrogen, $\mathrm{NH}_{4}-\mathrm{N}$; nitrite- $\mathrm{N}, \mathrm{NO}_{2}-\mathrm{N}$; nitrate- $\mathrm{N}, \mathrm{NO}_{3}-\mathrm{N}$ in $\mathrm{mg} / \mathrm{l}$ ) in the lagoon

\begin{tabular}{|c|c|c|c|c|c|c|c|c|c|c|c|c|c|c|c|c|}
\hline \multirow{2}{*}{ Basin } & \multicolumn{4}{|c|}{$\mathrm{T}-\mathrm{N}$} & \multicolumn{4}{|c|}{$\mathrm{NH}_{4}-\mathrm{N}$} & \multicolumn{4}{|c|}{$\mathrm{NO}_{2}-\mathrm{N}$} & \multicolumn{4}{|c|}{$\mathrm{NO}_{3}-\mathrm{N}$} \\
\hline & $\mathrm{Sp}^{*}$ & $\mathrm{Su}^{1)}$ & $\mathrm{Au}$ & Wi & Sp & $\mathrm{Su}$ & $\mathrm{Au}$ & Wi & $\mathrm{Sp}$ & $\mathrm{Su}$ & $\mathrm{Au}$ & $\mathbf{W i}$ & $\mathrm{Sp}^{*}$ & $\mathrm{Su}$ & $\mathrm{Au}$ & $\mathrm{Wi}$ \\
\hline No. 1 & 100.0 & 56.3 & 76. & 3.0 & 10.7 & 52.5 & 60.8 & 7 & 0.03 & 0.03 & 0.03 & 0.21 & 0.11 & 0.38 & 0.00 & 0.32 \\
\hline No. 2 & 76.8 & 70.1 & 74.4 & 86.0 & 14.1 & 67.0 & 63.2 & 49.7 & 0.02 & 0.03 & 0.02 & 0.21 & 0.02 & 0.15 & 0.01 & 0.55 \\
\hline No. 6 & 38.8 & 19.9 & 20.2 & 47.9 & 10.4 & 13.5 & 14.7 & 29.2 & 0.05 & 0.04 & 0.04 & 0.17 & 0.03 & 0.10 & 0.03 & 0.45 \\
\hline
\end{tabular}

1) The same samples in Table 1 except $\left({ }^{*}\right)$, of which data were on June 1 in 1995. 
abundance of spore-forming bacteria may also reflect the changeable conditions of temperature and nutrient

Table 4. Water characteristics (total phosphorus, T-P ; phosphate-P, $\mathbf{P O}_{4}-\mathbf{P}$ in $\mathrm{mg} / l$ ) in the lagoon

\begin{tabular}{|c|c|c|c|c|c|c|c|c|}
\hline \multirow{2}{*}{ Basin } & \multicolumn{4}{|c|}{$\mathrm{T}-\mathbf{P}$} & \multicolumn{4}{|c|}{$\mathrm{PO}_{4}-\mathrm{P}$} \\
\hline & $S p^{1)}$ & $\mathrm{Su}$ & $\mathbf{A u}$ & $\mathrm{Wi}$ & $\mathrm{Sp}$ & $\mathrm{Su}$ & $\mathrm{Au}$ & $\mathbf{W i}$ \\
\hline No. 1 & 20.1 & 29.2 & 13.5 & 19.4 & 2.7 & 9.5 & 10.1 & 14.2 \\
\hline No. 2 & 15.1 & 31.2 & 13.4 & 16.8 & 2.5 & 9.0 & 9.8 & 13.3 \\
\hline No. 6 & 11.6 & 19.8 & 8.1 & 12.4 & 2.1 & 7.7 & 5.9 & 10.4 \\
\hline
\end{tabular}

1) The same samples in Table 1. in the lagoon. Ammonia- or nitrite-oxidizing microbes were less than the detectable level in most of the samples (Table 8). These data agree with the low concentration of nitrite and nitrate in the basins, which suggested that a limited amount of ammonia was nitrified. Therefore, ammonia in the wastewater may be removed not by nitrification but by ammonia assimilation of microbes. Although it is generally considered that organic nitrogen is removed from wastewater by microbes through the nitrification and denitrification $^{4}$, ammonium assimilation by microbes must be paid attention as one of the important

Table 5. Microbial flora (aerobically cultured microbes, aerobes; anaerobically cultured microbes, anaerobes; fungi in $\log \mathrm{CFU} / \mathrm{ml}$ ) in the lagoon

\begin{tabular}{|c|c|c|c|c|c|c|c|c|c|c|c|c|}
\hline \multirow{2}{*}{ Basin } & \multicolumn{4}{|c|}{ Aerobes } & \multicolumn{4}{|c|}{ Anaerobes } & \multicolumn{4}{|c|}{ Fungi } \\
\hline & $\mathrm{Sp}^{1)}$ & $\mathrm{Su}$ & $\mathrm{Au}$ & Wi & $\mathrm{Sp}$ & $\mathrm{Su}$ & $\mathrm{Au}^{*}$ & Wi & $\mathrm{Sp}$ & $\mathrm{Su}$ & $\mathrm{Au}$ & Wi \\
\hline No. 1 & 6.7 & 5.7 & 5.9 & 6.3 & 6.7 & 5.8 & 5.8 & 5.4 & 2.5 & 2.0 & 2.2 & 3.0 \\
\hline No. 2 & 6.4 & 5.6 & 5.8 & 5.9 & 6.4 & 5.8 & 5.3 & 4.7 & 1.3 & 2.7 & 1.9 & 3.0 \\
\hline No. 6 & 5.9 & 4.9 & 4.5 & 5.1 & 5.9 & 4.6 & 4.7 & 5.3 & 1.3 & 2.3 & 1.8 & 2.7 \\
\hline
\end{tabular}

1) The same samples in Table 1 except (*), of which data were on October 31 in 1995.

Table 6. Microbial flora (actinomycetes, bacilli and pseudomonads in $\log \mathrm{CFU} / \mathrm{m} l$ ) in the lagoon

\begin{tabular}{|c|c|c|c|c|c|c|c|c|c|c|c|c|}
\hline \multirow{2}{*}{ Basin } & \multicolumn{4}{|c|}{ Actinomycetes } & \multicolumn{4}{|c|}{ Bacilli } & \multicolumn{4}{|c|}{ Pseudomonads } \\
\hline & $\mathrm{Sp}^{1)}$ & $\mathrm{Su}$ & $\mathrm{Au}$ & $\mathrm{Wi}_{\mathrm{i}}$ & $\mathrm{Sp}$ & $\mathrm{Su}$ & $\mathrm{Au}$ & Wi & $\mathrm{Sp}$ & $\mathrm{Su}$ & $\mathrm{Au}$ & Wi \\
\hline No. 1 & 3.6 & 4. 2 & $<3.3$ & 4.1 & 4.2 & 3.4 & 3.8 & 4.7 & 3.9 & 2.8 & 2.5 & 2.3 \\
\hline No. 2 & $<3.3$ & 4. 1 & $<3.3$ & 4.3 & 4.1 & 4.3 & 3.9 & 4.2 & 3.1 & 3.0 & 2.6 & 3.0 \\
\hline No. 6 & $<3.3$ & 4.0 & 3.7 & 3.8 & 4.0 & 3.8 & 4.5 & 4.2 & 2.0 & 2.3 & 1.9 & 2.6 \\
\hline
\end{tabular}

1) The same samples in Table 1.

Table 7. Microbial flora (enterobacteriaceae, streptococci, clostridia in $\log \mathrm{CFU} / \mathrm{m} l$ ) in the lagoon

\begin{tabular}{|c|c|c|c|c|c|c|c|c|c|c|c|c|}
\hline \multirow{2}{*}{ Basin } & \multicolumn{4}{|c|}{ Enterobacteriaceae } & \multicolumn{4}{|c|}{ Streptococci } & \multicolumn{4}{|c|}{ Clostridia } \\
\hline & $\mathrm{Sp}^{1)}$ & $\mathrm{Su}$ & $\mathrm{Au}$ & Wi & $\mathrm{Sp}$ & $\mathrm{Su}$ & $\mathrm{Au}$ & Wi & $\mathrm{Sp}$ & $\mathrm{Su}$ & $\mathrm{Au}^{*}$ & $\mathrm{Wi}$ \\
\hline No. 1 & 4.8 & 3.9 & 4.2 & 4.5 & 5.3 & 4.6 & 3.7 & 4.8 & 2.0 & 4.0 & 5.3 & 4.5 \\
\hline No. 2 & 5.2 & 4. 2 & 4.7 & 3.4 & 4.5 & 4.1 & 3.1 & 4.1 & 1.6 & 4. 1 & 4.4 & 4.5 \\
\hline No. 6 & 4.6 & 1.6 & 3.0 & 3.7 & 4.1 & 3.4 & 1.3 & 3.4 & 1.8 & 3.6 & 4.4 & 3.8 \\
\hline
\end{tabular}

1) The same samples in Table 1 except $\left({ }^{*}\right)$, of which data were on October 31 in 1995. 
NAKAI, ABE, KOHDA and ANDO

Table 8. Numbers of nitrifying microbes $(\log \mathrm{MPN} / \mathrm{m} l)$ in the lagoon

\begin{tabular}{|c|c|c|c|c|c|c|c|c|}
\hline \multirow{2}{*}{ Basin } & \multicolumn{4}{|c|}{$\begin{array}{l}\text { Ammouium oxidizing } \\
\text { microbes }\end{array}$} & \multicolumn{4}{|c|}{$\begin{array}{c}\text { Nitrite oxidizing } \\
\text { microbes }\end{array}$} \\
\hline & $\mathrm{Sp}^{1)}$ & $\mathrm{Su}$ & $\mathrm{Au}$ & $\mathrm{Wi}_{\mathrm{i}}$ & $S p$ & $\mathrm{Su}$ & $\mathrm{Au}$ & $w_{i}$ \\
\hline No. 1 & $<0.4$ & $<0.4$ & $<0.4$ & $<0.4$ & 2. 2 & $<0.4$ & $<0.4$ & $<0.4$ \\
\hline No. 2 & 0.5 & $<0.4$ & 0.4 & $<0.4$ & 1.5 & $<0.4$ & $<0.4$ & $<0.4$ \\
\hline No. 6 & $<0.4$ & $<0.4$ & $<0.4$ & $<0.4$ & $<0.4$ & $<0.4$ & $<0.4$ & 0.7 \\
\hline
\end{tabular}

1) The same samples in Table 1.

processes in the wastewater treatment. Since microbes which assimilated ammonia may form a large volume of sedimented sludge, accumulated sludge should be removed from basins. Sludge can be applied as fertilizer on the grass- or crop-land ${ }^{9)}$.

Lagoon systems have disadvantages in the possibility of runoff or permeation into ground water ${ }^{1,5)}$; however, they have great advantages in stability of treatment in all seasons and simplicity of maintenance as we observed. We think that the lagoon system is one of the prosperous systems of treatment and recycle of wastewater in the sustainable animal production.

\section{Acknowledgments}

This study was partly supported by a Grant-in-Aid (Nos. 06760292 and 07555460) for Scientific Research from the Ministry of Education, Science, Sports and Culture, a Grant for Research Project of Establishment of High-level Processing Techniques and Utilization of Livestock Waste in Environmental Pollution Control from the Ministry of Agriculture, Forestry and Fisheries, Research Grants for Meat and Meat Products from the Ito Foundation, and a Grant in Aid for Scientific Research from the Ministry of Health and Welfare and Japan Education Center of Environmental Sanitation.

\section{References}

1) Ackerman EO, Taylor AG. Stream impacts due to feedlot runoff. In : Animal Waste and the Landwater Interface. (Steele K ed.) 119-125. CRC Press, Inc. Baca Raton. 1995.

2) Ad hoc committee for standard analytic methods for water quality. Water Analytic Methods, 1993 ed. 62205. Japan Water Association. Tokyo. 1993.

3) Alexander M, Clark FE. Methods of Soil Analysis Part 2. 1st ed. 1477-1483. American Society of Agronomy Inc. Madison. 1965.

4) Cole JA. Biodegradation of inorganic nitrogen compounds. In : Biochemistry of Microbial Degradation. (Ratledge $\mathrm{C}$ ed.) 487-506. Kluwer Academic Publishers. Dordrecht. 1949.

5) Correll DL, Jordan TE, Weller DE. Livestock and pasture land effects on the water quality of Chesapeake Bay watershed streams. In : Animal Waste and the Land-water Interface. (Stcele $\mathrm{K}$ ed.) 107 117. CRC Press, Inc. Boca Raton. 1995.

6) Hayakawa $M$, Nonomura $H$. Selective Isolation of Actinomycetes. 1st ed. 4-38. Japanese Society of Actinomycetes. Tokyo. 1993.

7) Kakiichi E, Kamata S, Uchida K. Studies on livestock excreta disposal by aerated lagoon. Reports of Nippon Veterinary and Animal Science University, $29: 117-121.1980$.

8) Nakai $Y$, Saito M, Nakatani M, Kohda C, Ando T, Inamoto $\mathrm{T}$, Ogimoto $\mathrm{K}$. Changes in microbial flora of animal feces after excretion. Animal Science and Technology, 68 : 138-143. 1997.

9) Smith SR. Agricultural Recycling of Sewage Sludge and the Environment. 155-156. CAB International. Wallingford. 1996.

10) Sweeten JM, Wolfe ML, Chasteen ES, Sanderson M, Auvermann BA, Alston GD. Dairy lagoon effluent irrigation : effects on runoff quality, soil chemistry, and forage yield. In : Animal Waste and the Landwater Interface. (Steele K ed.) 99-106. CRC Press, Inc. Baca Raton. 1995.

11) White RK. Lagoon systems for animal wastes. In : Animal Wastes. (Taiganides EP ed.) 213-232. Applied Science Publishers Ltd. London. 1977. 